November 5 later in the day in the southern parts of North Island, and (3) on November 24 in the southwest parts of South Island.

In Spain during the same month, twenty-five earthquakes were registered by the seismographs at the Geophysical Observatory at Toledo. The earthquake of November 11 , registered at $22 \mathrm{~h}$. $57 \mathrm{~m}$. $51 \mathrm{~s}$. G.M.T., had an estimated epicentral distance from Toledo of $370 \mathrm{~km}$. and a focal depth of $25 \mathrm{~km}$. Its epicentre is likely to have been in the neighbourhood of lat. $37 \cdot 4^{\circ} \mathrm{N}$., long. $1 \cdot 7^{\circ} \mathrm{W}$., which is just west of the town of Aquilas on the Mediterranean coast of Spain. The earthquake was felt at Granada with intensity $V$.

\section{Study of Physical Medicine}

According to the Journal of the American Medical Association of December 25, the first centre for the scientific study and development of physical medicine as a branch of medical practice has been established by the National Foundation for Infantile Paralysis in the Graduate School of Medicine of the University of Pennsylvania. The centre will include a department for development of physical medicine as a scientific part of the practice of medicine, a training centre for medical leaders and teachers in this branch of medicine, and a school for training technical workers. The departments of anatomy, physiology pathology and other basic sciences of the University of Pennsylvania will co-operate in this proposed programme.

\section{The Chronica Botanica Co.}

THe Chronica Botanica Co., of Waltham, Mass., has issued a special edition of Dr. C. A. Browne's "Thomas Jefferson and the Scientific Trends of his Time" (an advance reprint from Chronica Botanica, 8) on the occasion of the tenth anniversary of its establishment. The Chronica Botanica Co. was founded in Leyden, the Netherlands, in September 1933, and was transferred to the United States early in 1940. An old, interesting, symbolic engraving, reproduced on an insert with the commemorative booklet, recalls the successful transfer of the firm's entire stock and its unique collection of source material in the history of botany and horticulture, just a few months before the invasion of the Low Countries. The firm, which is directed by Dr. Frans Verdoorn, publishes Chronica Botanica, "A New Series of Plant Science Books" and Annales Cryptogamici et Phytopathologici (formerly Annales Bryologici). Special projects in the course of preparation include: "Plants and Plant Science in Latin America" and the "Index Botanicorum".

\section{American Academy of Arts and Sciences Grants}

INCOME from the Permanent Science Fund of the American Academy of Arts and Sciences is used to support scientific research in the fields of mathematics, physics, chemistry, astronomy, geology, geography, zoology, botany, anthropology, psychology, sociology and economics, history and philology, engineering, medicine, surgery, agriculture, manufacture and commerce, education, or any other science of any nature or description. Equipment purchased outright through a grant from the Fund is subject to reassignment by the committee of award, upon termination of research in the particular field of endeavour in support of which a grant is made. Grants are not made for the financial support of work the results of which comprise partial fulfilment of requirements for an academic degree. It is a policy of the committee of award not to approve requests for general permanent equipment for institutions. Applications for grantsin-aid should be made on forms to be obtained from the chairman of the committee, and will be considered on June 1 and October 1. Communications should be addressed to John W. M. Bunker (chairman), Permanent Science Fund Committee, Massachusetts Institute of Technology, Cambridge 39, Massachusetts.

\section{Announcements}

The Executive Council of the Imperial Agricultural Bureaux has elected Mr. G. H. Creasy (Colonial Empire) as chairman in succession to Mr. Shamaldhari Lall (India). Lieut.-Colonel J. G. Robertson, representative on the Council of the Dominion of Canada, was elected vice-chairman.

The Colonial Office announces that Dr. E. E. Williams, of Trinidad, has been appointed secretary of the Agricultural Committee of the Caribbean Research Council. Dr. Williams, who has been assistant professor of social and political science at Howard University, Washington, has made a special study of economic problems in the British West Indies. He was born in 1911, and graduated at the University of Oxford.

The Secretary of State for the Colonies has decided, after consultation with the Governors of Northern Rhodesia and Nyasaland, to appoint a joint development adviser for the two territories, and Mr. G. F. Clay, director of agriculture in Uganda, has been appointed to the post. Mr. Clay has recently served as director of supplies for Uganda and director of native production for East Africa.

MaNy have been wondering how the gypsies have fared during the European War. After all, less than rnost folk are they concerned with the social and economic causes which have given rise to the present conflagration. The present issue of the Journal of the Gypsy Lore Society (23, pts. 1-2) contains the life and travels of Peter Lazarovic the Rudar, a vivid account of the story of an old gypsy who has had a chequered existence. There is also an interesting study of Esther Young, an English gypsy witch.

ThE annual report of the Board of Regents of the Smithsonian Institution for the year ended June 30, 1941, which has already been noted in NATURE (149, $326 ; 1942$ ), has now been issued as a bound volume (Washington, D.C. : Gov. Printing Office. 2 dollars) containing in a general appendix the customary miscellaneous selection of papers, some of them original, covering a wide range of scientific investiga tion and discussion. This appendix runs to some 450 pages. Among the papers not previously published elsewhere are those by E. P. Walker on "Care of Captive Animals"; F. C. Craighead on "The Influence of Insects on the Development of Forest Production and Forest Management", and F. C. Chase on "Useful Algæ". A number of others, such as those of H. C. Hottel on "Artificial Converters of Solar Energy" ; J. W. Lasley, jun., on "Mathematics and the Sciences"; H. E. Munsell on "Vitamins and their Occurrence in Foods"; and W. N. Fenton on "Contacts between Iroquois Herbalism and Colonial Medicine", are now made more accessible to scientific workers. 